\title{
BRYGIDA HELBIG-MISCHEWSKI
}

\section{Nałkowska i Komornicka, czyli kto zawinił}

Gdyby popełniono tu zbrodnię, to Zofia Nałkowska miałaby motyw. Po zapaści i zniknięciu Komornickiej została najinteligentniejszą, najbardziej doświadczoną, najodważniejszą, najbardziej radykalną autorką - i mogła się spodziewać, że nie znajdzie równych sobie $\mathrm{w}$ powieści dla kobiet ${ }^{\mathrm{I}}$.

Tak pisze w swej genialnej monografii o Marii Komornickiej Izabela Filipiak, stawiając Zofię Nałkowską w stan oskarżenia. Gdy badacze, zwłaszcza badacze Komornickiej, zestawiają dzisiaj ze sobą obie pisarki, to najczęściej właśnie w ten sposób Komornicką w pozycji osoby przegranej i skrzywdzonej, Nałkowską w pozycji osoby wygranej i oskarżonej. Sugestywność i ostrość takich przeciwstawień, którymi w pewnej mierze sama posługiwałam się w monografii o Komornickiej Stracona bogini ${ }^{2}$, niekoniecznie jednak musi wynikać $\mathrm{z}$ ich słuszności. Ładunek emocjonalny, z jakim mówi się o obu pisarkach, świadczy raczej o tym, że ich wzajemna relacja jest niezbadanym pustym miejscem i powierzchnią projekcyjną dla tematów naszej własnej egzystencji.

Zainspirowana recenzją mojej książki autorstwa Arlety Galant ${ }^{3}$ spróbuję więc napisać o relacji obu pisarek, pozostając z boku, na pozycji obserwatorki, nie dając się „wciągnąć”

I I. Filipiak, Obszary odmienności. Rzecz o Marii Komornickiej, Gdańsk 2006, s. 322. Cytaty pochodzące z tej publikacji oznaczam w tekście zasadniczym skrótem $\mathrm{O}$ oraz numerem strony zapisanymi w nawiasie.

${ }^{2}$ B. Helbig-Mischewski, Stracona bogini. Rzeczo Marii Komornickiej, Kraków 2010. Wersja niemiecka: B. Helbig-Mischewski: Ein Mantel aus Sternenstaub. Geschlechtstransgress und Wabnsinn bei Maria Komornicka, Norderstedt 2004.

3 Zob. też recenzję: A. Galant, Trupy na brzegu, „Pogranicza” 2011, nr 6, s. $56-57$. 
$\mathrm{w}$ poetykę utożsamiania się z jedną z nich, w dynamikę łatwych oskarżeń. Oczywiście, nie da się już odtworzyć tego, jak było „naprawdę”, można jednak próbować zobiektywizować spojrzenie lub spojrzeć na problem od zupełnie innej strony.

Maria Komornicka (1876-1949) i Zofia Nałkowska (1885-1954). Pierwsza znana jest w Polsce wyłącznie specjalistom od literatury Młodej Polski albo feministkom, druga - nie tylko weszła na stałe do kanonu literatury polskiej, lecz jest jej pierwszą damą (albo drugą, po Wisławie Szymborskiej). Pierwsza kojarzy nam się z rozwichrzoną, szaloną młodą dziewczyną albo zaniedbanym dziadziem Piotrem, „głupim Petrkiem”, jak wołały podobno za Komornicką dzieci, druga - z elegancką kobietą o zadbanej fryzurze, inteligentną i kokieteryjną. Nałkowska stała się po II wojnie światowej i napisaniu Medalionów autorytetem moralnym, Komornicka - w młodości cudowne dziecko, umarła jako „wariatka”, a jeśli się nią interesowano po wojnie, to pod katem tego, „z jakim dziwadłem mamy do czynienia" ${ }^{4}$. Dzisiaj zainteresowanie wraca w ramach studiów gender i badań nad Innością w kulturze. Jednak nie wydaje się, aby w najbliższym czasie ta doskonała poetka, autorka dramatów i rebelianckiej prozy oraz krytyczka literatury miała znaleźć swoje miejsce w kanonie literatury polskiej. W przeciwieństwie do Zofii Nałkowskiej Maria Komornicka znacznie przekraczała granice przyzwoitości w życiu i sztuce, więc wpisano ją w stereotyp histeryczki, kobiety nieobliczalnej, a jako taka nie może zasiąść - w przeciwieństwie do poetów przeklętych - na literackim tronie. Może wzbudzać litość, stać się przedmiotem psychologicznych analiz, może również zostać bohaterką i symbolem zbuntowanych feministek. Stać się dla Polaków autorytetem, jak Zofia Nałkowska - prawdopodobnie nie, w każdym razie jeszcze nie w tym momencie. Autorka Granicy okazała się jedną z przewodniczek emancypacji polskich kobiet i polskiej prozy młodopolskiej, autorkę Biesów wyparto z pamięci kulturowej, wraca ona do niej bardzo powoli. Gdybyśmy zestawili obie te postaci z bohaterkami powieści Charlotte Brontë Jane Eyre, to Nałkowska byłaby emancypującą się, ale jednocześnie rozważnie pertraktującą z patriarchatem Jane, Komornicka zaś szaloną pierwszą żoną Mr. Rochestera, o której istnieniu ten pragnie zapomnieć, upchniętą na strychu i straszącą po nocach, a w końcu rzucającą się w płomienie. Komornickiej się boimy, Komornicka też mogłaby straszyć nas po nocach nie tylko swoją biografią, ale i niektórymi utworami, zwłaszcza z nieopubli-

\footnotetext{
4 Tę optykę zmieniły dopiero Maria Podraza-Kwiatkowska i Maria Janion.
} 
kowanej Xiegi poezji idyllicznej. Mówi w nich o sprawach nieprzyjemnych, porusza kwestie, o których wolelibyśmy nic nie wiedzieć. W swej monografii Filipiak, odwołując się do Marii Janion, mówi o widmowej kondycji Komornickiej w naszej kulturze, Komornicka to dla niej „żywy trup”, banita powracający na miejsce wygnania.

Badacze Komornickiej czynią jednak w ostatnich latach wszystko, żeby banicie oddać sprawiedliwość oraz należne mu miejsce w historii literatury, czyli godnie go pogrzebać, jak nazywa to Filipiak. Czynią to niekiedy kosztem Nałkowskiej, gdyż bardzo mocno odczuwają niesprawiedliwość, jaka tkwi w fakcie, że Komornicką - choć była, zdaje się, wybitniejsza i bardziej wyrazista, a w młodości inspirowała tamtą i pozostała jej (niekoniecznie chcianym i lubianym, ale podziwianym) wzorem - spotkał tak okropny los. Ta niesprawiedliwość boli. Wpisuje się w inne znane nam narracje o nagonce i zaszczuciu Innego.

Obie pisarki można by pod kątem spektakularnych przeciwieństw zestawiać bez końca, mogłoby brzmieć to na przykład tak: Zofia Nałkowska z córki niezamożnego przedstawiciela inteligencji awansowała do arystokracji ducha - Maria Komornicka przyszła na świat jako arystokratka i ,stoczyła się” do przytułku dla ubogich. Historia jednej jest narracją o wzlocie, drugiej o upadku. Jedna została wyniesiona, druga - zapomniana, jedną się szczycimy, drugą wystawiamy na freak-show. W swej inności jednak biografie Komornickiej i Nałkowskiej nie tylko się odpychają, ale i przyciągają, jakby jedna nie mogła żyć bez drugiej, jakby Maria była negatywem, koniecznym uzupełnieniem Zofii, albo jakby były postaciami uwiecznionymi na dwóch stronach tego samego medalu. Zapewne też, gdyby poznały się w innych, nie traumatyzujących okolicznościach, wszystko mogło potoczyć się zupełnie inaczej.

Wróćmy do cytatu przytoczonego na początku moich rozważań. Izabela Filipiak uważa, że na Marii popełniono społeczną zbrodnię, bada ślady wykluczania i upokarzania Komornickiej, albo ślady obojętności, cichej radości z jej nieszczęścia, tropy wskazujące na nieudzielenie jej pomocy, na jej izolację, samotność, ostracyzm wobec niej ze strony dawnych przyjaciół literatów, nawet tych z tzw. obozu postępowego. Nałkowska jest zdaniem Filipiak, obok na przykład Miriama, jedną z osób, które nie przejęły się losem Komornickiej, gdy ta najbardziej tego potrzebowała. Więcej, potajemnie cieszyła się jakoby z nieszczęścia Komornickiej i na nim budowała własną karierę. Filipiak czyni ją współodpowiedzialną za dokonany na Komornickiej symbo- 
liczny mord, gdyż to właśnie ona miałaby najwięcej zyskać na nieszczęściu Marii.

Według Filipiak, a także Edwarda Bonieckiego5, Zofia Nałkowska jest tą, która przechwytuje niejako życie Komornickiej, „kradnie jej list”, która inspiruje się nią, niejako żeruje na niej, a jej prochy wykorzystuje jako nawóz - Zofia Nałkowska idąca po trupach. Wyczuwa się w tej optyce wielkie rozgoryczenie badaczki, które zresztą nie dziwi. Kiedy zagłębimy się w biografię i twórczość Komornickiej, zaczynamy odczuwać wobec niej głębokie wpółczucie, rozumieć, że wydarzyła się tu jakaś autentyczna tragedia, że ktoś o niezwykłym potencjale został zapomniany, że zniszczyli go i zaszczuli Kleingeister, ludzie o niskiej kulturze, pełni zawiści, nietolerujący tego, co Inne i większe od nich, zaś przyjaciele milczeli. O takim zaszczuciu pisze Komornicka w Biesach. Takie tragedie zdarzają się nierzadko, ale przykład Komornickiej jest pokazowy, ekstremalny. Żeby to zrozumieć, trzeba znać teksty Komornickiej, jej „wywrotową” poezję i prozę artystyczną, jej płomienną krytykę literacką, jej późniejsze, pełne rozpaczy listy z „domu wariatów”, jej jeszcze w całości nieopublikowaną Xięgę poezji idyllicznej ${ }^{6}$, przesyconą głęboką goryczą i wisielczym humorem, ale będącą również mistyczną próbą pogodzenia się z tym, co już się stało i się nie odstanie, próbą przekucia tego w mądrość i dojrzałość. Trzeba znać jej powojenne listy, w których wyrażała nieśmiałą nadzieję na to, że dawni przyjaciele pomogą jej wrócić do literatury, nadzieję, że odwiedzi ją może także Zofia Nałkowska, z którą łączyły ją więzy wspólnie przeżytego, bardzo intensywnego czasu u schyłku wieku XIX, wspólne tematy literackie, wspólny światopogląd, a także trzy osoby, które im obu były bliskie (lecz Nałkowskiej dłużej): Wacław Nałkowski, Cezary Jellenta, Zofia Villaume-Zahrtowa.

Jeśli znamy biografię i teksty Komornickiej, jeśli znamy również dynamikę nagonek na osoby odstające od normy i orientujemy się w kwestiach dyskryminacji kulturowej kobiet, trudno nam nie zgodzić się z Filipiak, gdy twierdzi, że to, co stało się z Komornicką, jest kulturową zbrodnią, której przesłanie powinno zapaść nam jako społeczeństwu głęboko w świadomość. Wyczuwamy też, że samej Filipiak o wiele bliższa jest „namiętna” Komornicka niż „kalkulująca” Nałkowska (O, s. 323). Au-

5 E. Boniecki, Modernistyczny dramat ciała. Maria Komornicka, Warszawa 1998. Zob. też: K.E. Zdanowicz, Kto się boi Marii K.? Sztuka i wykluczenie, Katowice 2004.

${ }^{6}$ M. Komornicka, Utwory poetyckie proza $i$ wierszem, red. M. Podraza-Kwiatkowska, Kraków 1996. 
torka monografii opowiada się jednoznacznie po stronie Komornickiej. Dlaczego? Bo zapewne jest tam już od dawna. Mówiąc o Komornickiej, mówi też o sobie. Podobnie zresztą jak inni badacze, w tym autorka niniejszego szkicu - jedni bardziej, inni mniej otwarcie. Gorycz Izabeli Filipiak pogłębia się wraz z refleksją o niewspółmierności talentu Zofii i Marii. Badaczka pisze:

Gdyby Komornicka rozwinęła swój talent dramatyczny i prozatorski, to stałaby się postacią większego formatu niż Nałkowska. Już w Halszce autorka stworzyła nieznany wcześniej portret ziemiańskiej sfery i udowodniła, że potrafi w nowy sposób przepisywać kulturowe wzory i tworzyć z nich nowe warianty. Twórcze ambicje Nałkowskiej są skromniejsze, przekształcanie kultury nie jest jej celem. Pisze obyczajowe powieści dla kobiet. $(\mathrm{O}, \mathrm{s} .322)$

Jeśli chodzi o ocenę talentu obu autorek, to także świetna badaczka Nałkowskiej, Hanna Kirchner, broniąca „swojej” pisarki przed zarzutami Filipiak, w imponującej najnowszej monografii wyraża zgodny z przytoczonym wyżej pogląd: „Obie były cudownymi dziećmi, ale umysłowość Marii nosiła cechy genialności" 7 . Przy Komornickiej Nałkowska jawi się jako mniej bezkompromisowa, ostrożniejsza, chociaż potrafiła też być płomienna i wyzywająca. Przywołajmy znowu opinię Filipiak:

Komornicka odmawia gestów asymilacji, jakich oczekuje się od autorki. To nie Nałkowska, która w swoim debiucie każe bohaterce słuchać tyrad na temat wad kobiecych i rozstrząsać - za i przeciw stawiane tam kwestie. Ona się nie tłumaczy. Wczesna Komornicka, wliczając Forpoczty, chce zostać przyjęta do kultury w całej odrębności. Jej żądanie jest skazane na pokazową klęskę. (O, s. 200)

Komornicka spala się w walce, jest męczennicą - tak zresztą nazwała ją już Maria Janion. Nałkowska to $\mathrm{z}$ kolei raczej narcystyczna dandyska, która jeśli walczy, to z bezpiecznej pozycji. Na Kongresie Kobiet w roku 1907 może nawet bronić „kobiet upadłych”, gdyż przemawia z pozycji mężatki. Nałkowska nie ma zamiaru polec w boju. Tymczasem Komornicka nie liczy strat, a gdy już zrozumie, do jakiej sytuacji doprowadziła ją bezkompromisowość, będzie za późno.

Autorka Narcyzy występuje w narracji Izabeli Filipiak (oraz wspomnianego Edwarda Bonieckiego, w pewnej mierze także

7 H. Kirchner, Natkowska albo życie pisane, Warszawa 2012, s. 57. 
Krystyny Kralkowskiej-Gątkowskiej ${ }^{8}$ i mojej) jako zwycięzczyni odczuwająca satysfakcję, mająca poczucie wyższości wobec poległej, osoba zimna i nieczuła na nieszczęście swojej wielkiej poprzedniczki, która przetarła jej drogę do literatury. Filipiak formułuje wobec Nałkowskiej następujące zarzuty:

1. Bezpodstawną zawiść, ale i ostracyzm wobec Komornickiej, między innymi przez nazwanie jej w Dziennikach (8 grudnia 1902 r.) , ,aktorką w gabinecie restauracyjnym” (O, s. 319).

2. Wykorzystanie zwierzeń wspólnej przyjaciółki Zosi Villaume, która - zanim poznała Nałkowską - przyjaźniła się z Komornicką, i (być może) rozpowszechnienie plotek o (być może) homoseksualnym charakterze ich relacji. „Przywłaszczenie sobie" przyjaźni Zosi.

3. Świadome szkodzenie Marii po jej zerwaniu z szykanującym ją pismem „Głos”, udział (choć nie bezpośredni) w intrygach przeciwko niej. Radość z jej porażek.

4. Robienie własnej kariery z myślą, „żeby pokazać” Maryni. Tutaj Filipiak także cytuje Dzienniki Nałkowskiej, służące za główny materiał dowodowy: Drukuje też nie dla świata - tylko dla paru ludzi, którzy mnie nienawidza: dla Maryni Komornickiej, Kucharskich, itp. (O, s. 319). Hanna Kirchner pisze w odpowiedzi Filipiak o „niechęci” między Nałkowską a Komornicką, „,o dziwne, obustronnej”, także opierając się na Dziennikach: „Łamiąca wszelkie konwenanse Komornicka musiała jednak krytycznie komentować zachowanie przemądrzałej pensjonarki. Zofia najpierw zarzeka się: Wolę zostać chyba dlatego nauczycielka, żeby nie triumfowata ani Radlinska, ani Marynia Komornicka, ani cała ta zgraja, która przepowiada mi burzliwa przysztość" (18 sierpnia 1900 r.), by za kilka miesięcy z mściwą satysfakcją odpłacić Marii miażdzącą, z gruntu „filisterską” opinią: Widziatam Marynię Komornicka, właściwie Lemańska, która obecnie zachownje sie jak aktork a w gabinecie restauracyjnym [...] (8 grudnia 1900 r.).

5. Traktowanie Komornickiej jako rywalki. Nałkowska obawiała się konkurencji. Była:

młodsza, bardziej powierzchowna i niejako skazana na naśladownictwo Maryni. Nie ma gorszego losu niż zostać kopią rewolucjonistki w restrykcyjnej kulturze, która zmusza niezależne artystki, by krążyły po jej obrzeżach jak wolne elektrony albo były dopusz-

${ }^{8}$ K. Kralkowska-Gątkowska, Cień twarzy. Szkice o twórczości Marii Komornickiej, Katowice 2002. 
czane pojedynczo. Gdyby zaakceptowano Komornicką, dla Nałkowskiej nie starczyłoby już miejsca. (O, s. 320)

Z kilku powodów silna Komornicka byłaby dla niej problemem. Są zbyt do siebie podobne - radykalne, płomienne, lewicujące i feminizujące, eksperymentujące z życiem i twórczością, niezależne. (O, s. 322)

Podobnie zresztą Hanna Kirchner znajduje w Dziennikach dowody na to, że Nałkowska widziała niebezpieczeństwo zostania naśladowczynią, kopią Komornickiej:

I tak dla zatkania gęby sumieniu - postanawiam, że wyjdę za mąż z zamiarem rozwodu za dwa lub trzy lata, jak to uczyniła Marynia Komornicka, która otrzymała obecnie separację. Ale przede wszystkim będzie to naśladownictwem Maryni, a tego strzegę się jak ognia9.

6. Przemilczenie informacji o obecności Komornickiej (której sztukę Kobieta nowa rok wcześniej wystawiono w Warszawie) w literaturze emancypacyjnej kobiet w referacie na Zjeździe Kobiet, a tym samym bezpośrednie przyczynienie się do jej „szaleństwa”, czyli ogłoszenia się mężczyzną, na skutek odczutego boleśnie wykluczenia. Hanna Kirchner nie zgadza się z tym poglądem.

7. Nieodwiedzenie chorej w ,domach wariatów" w latach 1907-1914. „Nie ma [...] żadnego dowodu na to, że Komornicka nienawidziła Nałkowskiej”, twierdzi Filipiak. Natomiast „Nałkowska odczuwa zarazem pogardę i satysfakcję, ten rodzaj satysfakcji, który rodzi się z przeczucia bliskiego upadku znienawidzonej osoby" (O, s. 319). Zwróćmy uwagę na głęboką ironię Izabeli Filipiak cytującej Dzienniki Nałkowskiej:

Ciężko mi pomyśleć, gdzie podziat się cudny talent i pochmurna dusza Komornickiej, zamkniętej od wielu lat w domu obłakanych. Komornicka znajdowała się akurat całkiem niedaleko, w Micinie pod Pruszkowem koło Warszawy. Można byłą ją tam odwiedzić, gdyby ktoś chciał się dowiedzieć, co się stało z jej duszą. Skąd się wziął ten nagły przypływ sentymentu? (O, s. 319)

8. Nieodwiedzenie Komornickiej w przytułku dla starców po II wojnie światowej. Filipiak znów cytuje Dzienniki: Wysła-

9 H. Kirchner, op.cit., s. 57. 
tam kartę do Zosi, która odnalazła Marynię Komornicką w jakimś przytutku dla starców, w nędzy [...]. Jakżebym chciała teraz tam pojechać - gdybym potrafiła. Także i tę niemoc Filipiak komentuje uszczypliwie: „Oto kobieta, która lata samolotem i bez lęku rozgląda się po koszmarach dnia (jak to skomentowała Komornicka w liście do Villaume), która patrzy na popioły Oświęcimia, a nie potrafi spojrzeć w twarz Marii Komornickiej” (O, s. 320).

A teraz wychylmy się poza Dzienniki Nałkowskiej, przyjrzyjmy się źródłom trudnej relacji obu pisarek. Skąd wzięła się, potwierdzona także przez Kirchner, uraza Zofii Nałkowskiej do Marii Komornickiej? Czy, jak pisze Boniecki, był to wynik jej „kompleksu Komornickiej” związany z historią powstania książki Forpoczty, rebelianckiej narracji antyfilisterskiej, pierwszego płomiennego manifestu Młodej Polski o bulwersującym współczesnych radykalizmie politycznym, społecznym, artystycznym? W tym kontekście trzeba zapytać także o mężczyzn ważnych dla obu pisarek - Wacława Nałkowskiego i Cezarego Jellentę.

Po opublikowaniu w roku 1892 tomu opowiadań Szkice osiemnastoletnia autorka została obrzucona stekiem obelg, a jednocześnie zwróciła na siebie uwagę dwóch wybitnych intelektualistów. Pierwszym z nich był socjolog, geograf, socjalista, myśliciel Wacław Nałkowski, ojciec dziesięcioletniej wówczas Zofii; drugim - pisarz i publicysta pochodzenia żydowskiego Cezary Jellenta, też żonaty, też już ojciec. Obaj - zachwyceni młodą autorką, jej geniuszem, niepokorną osobowością, rewolucyjnym zapałem. Byli zainspirowani, oczarowani, może zakochani. Wiele lat później we wspomnieniach zatytułowanych Zapomniana awangarada ${ }^{\text {I0 }}$ Jellenta pisał o Nałkowskiej i Komornickiej. Co do tej pierwszej - nie ma wątpliwości, że uformował ją ojciec, o drugiej pisze tak:

Ale skąd się wziął ten genialny gnom w spódnicy, ta żywa puszka Pandory: szyderstw, ironii, parodii i karykatur, ta staroszlachecka, słowiańska boginka [...], osoba drobnej statury, gdy gniewna, to trzęsąca się cała gebrycznie, gdy zachwychona, to miotająca, zdawało się, iskry ze swych bujnych kasztanowatych włosów i ogromnych brunantych oczów, paradoksalna mieszanina buty i naiwności życiowej, zgrzydliwości i słodyczy niewymownej ${ }^{\mathrm{II}}$.

Fragment ów zdradza temperaturę relacji, przynajmniej ze strony Jellenty, a zamieszczone w Forpocztach komentarze Nał-

ro C. Jellenta, Zapomniana awangarda, „Pion” 1935, s. 29.

${ }^{\text {II }}$ B. Helbig-Mischewski, op.cit., s. 188. 
kowskiego do Szkiców czarującej autorki również dają do myślenia. Sama Komornicka opisała prawdopodobnie swój związek z Jellentą (być może romans) w wierszu Do autora w przesileniu, zamieszczonym również w Forpocztach ${ }^{\mathrm{I} 2}$. Izabela Filipiak dogłębnie analizuje stosunek Nałkowskiego i Jellenty do Komornickiej, fascynację, a potem odwrócenie się, obojętność, nawet zgryźliwe uwagi o niej na łamach prasy. Zdaniem (niebezpodstawnym) Izabeli Filipiak Nałkowski i Jellenta co prawda promowali Komornicką, lecz także wykorzystywali do własnych celów jej młodzieńczy zapał, żarliwość, idealizm i naiwność, a kto wie, czy nie wiązali z nią jeszcze innego rodzaju nadziei. Komornicka wyjątkowo płomiennie broniła atakowanego w prasie i wykluczanego ze środowisk twórczych Jellenty, bardzo sobie szkodząc,

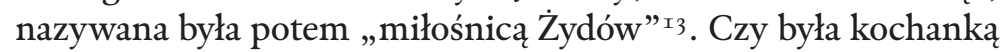
Nałkowskiego lub Jellenty, nie dowiemy się nigdy, aczkolwiek wiadomo, że spędziła $\mathrm{z}$ Jellentą ( $\mathrm{w}$ którym później zakochana była Nałkowska) kilka tygodni na wycieczce w Saskiej Szwajcarii, co w tamtych czasach musiało zostać uznane za skandal.

Jeszcze większe oburzenie wzbudziło samowolne zamieszkanie osiemnastolatki w domu Wacława i Anny Nałkowskich po powrocie z Cambdrige, co doprowadziło (jak twierdzi rodzina Komornickiej i do czego przychyla się także Filipiak) do zawału serca jej ojca Augustyna Komornickiego (5 maja 1895 r.), wobec którego młoda pisarka od młodości się buntowała. Wyrzuty sumienia z tego powodu będą dręczyć Komornicką całe życie - to jeden z najbardziej tragicznych wątków jej egzystencji, a zarazem jedna z największych różnic między nią a Zofią Nałkowską, którą ojciec intelektualista zawsze będzie wspierał. Maria tymczasem pozostanie z głębokim poczuciem winy wobec ojca - sprzeniewierzyła się jego światopoglądowi i radom życiowym, stając się, jak mówiono, przyczyną jego śmierci. To ojciec będzie głównym tematem jej obłędu, to jego będzie rehabilitować i wynosić pod niebiosa w listach do matki, a później w Xiędze, jakby czując, że powinna oddać mu sprawiedliwość.

Stosunek Nałkowskiej do matki i siostry również wydaje się mniej skomplikowany niż stosunek Komornickiej do matki i rodzeństwa. Nałkowska jest mniej obciążona toksycznymi relacjami z rodzicami, trudnymi emocjami, mniej straumatyzowana, ma więcej wsparcia $\mathrm{w}$ rodzinie, nie popada $\mathrm{w}$ tragiczny konflikt $\mathrm{z}$ nią. Pewnie łatwiej więc Nałkowskiej nie zwariować, postępować mniej impulsywnie, w sposób bardziej przemyślany. Nie

I2 Więcej na ten temat - zob. ibidem, s. 213-250.

s3 Ibidem, s. 231. 
płaci tak wysokiej ceny za swe wyzwolenie jak Komornicka, którą „zabijają” upokorzenia, ale i poczucie winy wobec ojca.

Nie oznacza to oczywiście, że Nałkowska nie miała żadnych traumatycznych przeżyć ani wynikających $\mathrm{z}$ nich powodów, by nie przepadać za Komornicką. Tutaj znowu warto zwrócić uwagę na kulisy powstawania Forpoczt, powołując się na wypowiedzi Filipiak i Kirchner.

Mamy rok 1895, w postępowym domu Nałkowskich pojawia się młoda, niezwykła kobieta, którą ojciec dziesięcioletniej Zofii jest zachwycony. Mała Zosia też jest nią zainspirowana, w Dziennikach wspomina później poważne rozmowy, które prowadziła z Marią jako dziecko „na Górkach”. W tym wszystkim jest jednak drugie dno. Żona Nałkowskiego - Anna z Safranków może odczuwać niepokój, a taka atmosfera nie uchodzi uwadze małej dziewczynki. Z korespondencji Komornickiej (list do Jellenty napisany już po odsunięciu się od niej Wacława) wynika, iż relacja jej i Nałkowskiego mogła budzić emocje i zastrzeżenia ze strony Anny:

Pozdrów Wacława i nie proś go w moim imieniu o list. Czy dobrze rozumiesz mechanizm jego oddalenia? Mnie się zdaje, że mam rozwiązanie: to ibsenizm. Woli „sam stać” niż zatruwać siebie rwaniem się w dwie strony i patrzeniem na chorobliwe wypieki Hani. „Dziecko piekieł" ze wszystkich uciech życia żąda tylko domowego spokoju, a ze wszystkich bólów życia odpycha ból nadczułego sumienia ${ }^{\mathrm{I} 4}$.

A więc Nałkowski - sugeruje młoda Komornicka - był w fazie tworzenia Forpoczt „dzieckiem piekeł”, teraz jednak ruszyło go sumienie (wypieki żony!) i pragnie już tylko spokoju w domu. Co wydarzyło się w jego życiu wcześniej, nie wiadomo.

Wyobraźmy sobie gorącą atmosferę, jaka panowała u Nałkowskich, gdy „osobliwy triumwirat”, jak wyraża się Filipiak, czyli „komunista, baba i Żyd” tworzyli Forpoczty, gdy Komornicka "rzuca się niczym samotny rycerz na pancerny garnizon wroga" (O, s. 221) w obronie Jellenty, sama zaś staje się inkarnacją głoszonych przez obu ubogich myślicieli idei i żywym sztandarem $\mathrm{w}$ ich walce przeciwko filistrom, a przy tym instrumentem walki o ich własne sprawy. Jest zbyt młoda i naiwna, żeby dokładnie zrozumieć, co się dzieje, i przewidzieć możliwe konsekwencje zdarzeń.

Jak na tę gorączkę mogła zareagować dziesięcio-, jedenastoletnia Zofia Nałkowska?

${ }^{{ }^{4} 4}$ H. Kirchner, op.cit., s. 59. 
Hanna Kirchner przytacza niezwykły wiersz dziewczynki pod tytułem Historia „Forpoczt”, w którym młoda pisarka odsłania przemilczaną w samych Forpocztach prawdę o powstaniu książki manifestu. Okazuje się, że autorów w rzeczywistości nie było troje, jak sugeruje okładka książki i jak pisze Komornicka w wierszu Grupa Laokoona, było ich czworo. Hanna Kirchner streszcza w ten sposób wierszyk małej Nałkowskiej:

Jest to alegoria wdzierania się czterech śmiałków na szczyt góry „wschodzącem słońcem prawdy - i wolności”. [...] Siły czterech odważnych były nierówne: pierwszy był mocarzem o twardych muskułach, zbrojnym w ciężki topór. Drugi, poeta, trzymał pęk kwiatów. Trzeci - „geniuszem od wszystkich uznany”, przybrany w królewskie szaty, świecił „błyszczącym herbem” i wydawał rozkazy schylonemu przed sobą niewolnikowi, by oczyścił drogę z ostów, cierni i głazów. [...] Wszyscy czterej stanęli na szczycie, tylko najmita padł wyczerpany, a oni, depcząc go, krzyczeli „Victoria”! A oto zwrotka ostatnia: „Jest nas troje, rzekłgeniusz, Laokoona grupa [...]”. Alegoria przedstawia Nałkowskiego, Jellentę i Komornicką - to ona jest geniuszem arystokratą i ona nazwała istotnie tę trójcę grupą Laokoona. Alegoria objawia, że ona też, dziewiętnastolenia Marynia, wykluczyła czwartego towarzysza niebezpiecznej wyprawy po prawdę $\mathrm{i}$ wolność z grona zwycięzców.

Biedna Anna, żona Wacława, która dziewczynce i jej nieporadnej muzie powierzyła swą gorycz! A dziecko prostodusznie dodało nawias pod wierszem: „(Nie jest to czysto mój wiersz: allegoryę wymyśliła mama, będąca właśnie tym najmitą - a ja tylko opisałam allegoryę tę wierszem)" ${ }^{15}$.

„Czy Wacław czytał ów wiersz?” - pyta Hanna Kirchner, podejrzewając Marię o wykorzystanie Anny Nałkowskiej jako najmity i nieuwzględnienie jej wśród autorów książki. O jednym jednak warto pamiętać: Komornicka ma wówczas 19 lat! Uczy się od swoich mistrzów. Jeśli „Wacław czytał”, to pozostaje mieć nadzieję, że uświadomił sobie, że to on, nie Maria, jest tym, który „najmuje” żonę.

Problemy małżeńskie czy poczucie odsunięcia, niedocenienia, goryczy Anna mogła przenieść na młodą Komornicką, mogła jej pozazdrościć oczywistości, z jaką ta przypisuje sobie prawo do autorstwa i uzurpuje sobie rolę geniusza, kreatora, a nie jedynie cichego pomocnika mężczyzn - pozazdrościć tego, czego Anna sobie odmówiła. Dowiadujemy się zatem z wierszyka młodziut-

I5 Ibidem, s. 27. 
kiej Nałkowskiej więcej o Annie i jej goryczy bycia wykorzystywaną przez męża niż o samej Komornickiej. Po latach Zofia pisze w Dzienniku, że życie jej matki było „smutne”, „otchłannie puste”, było „jednym łańcuchem krzywd i rozczarowań” ${ }^{16}$. Hanna Kirchner mówi o „cichym życiu” Anny „w cieniu bojownika” ${ }^{17}$. Widzimy, że nie Maria była tu największym problemem. Jednak winą Anna Nałkowska - a wraz z nią jej empatycznie przeżywająca tę sytuację córka, sama zapewne również niepozbawiona uczucia zazdrości o ojca - zdaje się obarczać dziewiętnastoletnią dziewczynę; tak zresztą przeważnie rozkładają się emocje w kulturach patriarchalnych. Sam Wacław po krótkim epizodzie zauroczenia Marią wraca zapewne emocjonalnie na łono rodziny, może się nawet tego epizodu wstydzi ${ }^{\mathrm{I} 8}$. O Komornickiej pisze w recenzji Baśni i psalmodii ironicznie, zwłaszcza po tym, jak autorka weszła w konflikt z „Głosem”

Dalszy ciąg przedstawia się następująco: Zofia będzie chciała niajako „pomścić” matkę, będzie zatem dążyć do tego, by stać się osobą, którą matka być nie mogła, by dorównać Komornickiej, czy nawet ją przewyższyć, zasługując tym samym na większy podziw ze strony ojca. Jeszcze po wielu latach, w roku 1953, można wyczuć u Nałkowskiej te emocje, gdy wspomina powstawanie Forpoczt w Dzienniku:

Ależ dziwna książka i dziwni ludzie, zwłaszcza Jellenta i Komornicka. Wielka pycha, drażliwość, maksymalne mniemanie o sobie. Trochę tych cech i u WN, ale niewątpliwie bardziej uzasadnione. $(6.10 .53)^{20}$

A może warto by przestać szukać problemu w Nałkowskiej i Komornickiej, przestać obarczać je jakąś wzajemną winą? To były bardzo młode dziewczyny - a dorośli, mądrzy, zdawałoby się, mężczyźni postawili je w sytuacji, która je przerastała i która uczyniła z nich rywalki. Gdyby ci mężczyźni postępowali wobec Komornickiej i Nałkowskiej (oraz jej matki) dojrzale, mogłyby one zostać przyjaciółkami. Jeśli popełniono tu zbrodnię, to nie popełniła jej żadna z pisarek.

I6 Ibidem.

I7 Ibidem, s. 13.

I8 Sugestia Izabeli Filipiak.

I9 Od tego czasu Komornicka będzie miała przeciwko sobie nie tylko obóz konserwatywny, ale i obóz postępowy.

${ }^{20}$ H. Kirchner, op.cit., s. 776. 


\section{BRYGIDA HELBIG-MISCHEWSKI}

\section{Nałkowska and Komornicka, or: Whose Fault It Was}

The author analyses the love-hate relationship between Zofia Nałkowska and her seven years' senior, the legendary painter Maria Komornicka, who was for a time romantically ivolved with Zofia's father - Wackaw Nałkowski - and her friend - Cezary Jellenta. The relationship between the two writers has excited emotional reponses from researchers for many years. Two critics specializing in Komornicka have shown their interest most explicitly: Izabela Filipiak and Edward Boniecki. They accuse Nałkowska of not maginalizing Komornicka's role in women's literature of early 20th century, of unfeeling attitude for Komornicka's tragic fate, even though Nałkowska was inspired by her in the early age, and of the failure to help Komornicka, when she was declared insane and disempowered after her symbolic transformation into a man. Researchers have so far seen Komornicka as a lost and harmed person, whereas Nałkowska was perceived as the morally questionable winner. However, Hanna Kirchner, who specializes in Nałkowska, has recently shown interesting sources of Nałkowska's dislike for Komornicka, pointing out to a forgotten juvenile poem called Historia „Forpoczt". The author of the article, who also wrote a monograph about Maria Komornicka, analyses the arguments presented by critics of both writers, observing the relation between Nałkowska and Komornicka from a neutral ground, without sharing the dynamic of hasty accusations.

Keywords: Nałkowska and Komornicka, rivarly between writers, feminist interpretation of author's biography, relations between Young Poland women authors, functions of patriarchal mentors, Wacław Nałkowski, Cezary Jellenta.

Brygida Helbig-Mischewski - doktor habilitowany, profesor Uniwersytetu Szczecińskiego, gdzie prowadzi zajęcia z kulturoznawstwa i komunikacji międzykulturowej, literaturoznawczyni i pisarka. Od roku 1983 przebywa w Niemczech, mieszka w Berlinie - tam wykłada polonistykę na Uniwersytecie Humboldtów. Najbardziej interesuje ją tematyka międzykulturowa oraz gender. Zaangażowana $\mathrm{w}$ działalność polsko-niemieckiego Instytutu Badawczego w Słubicach (Uniwersytet Adama Mickiewicza, Viadrina). Autorka monografii poświęconej Marii Komornickiej, Stracona bogini (2010). Wersja niemiecka tej książki nosi tytuł Ein Mantel aus Sternenstaub. Gescblechtstransgress und Wabnsinn bei Maria Komornicka (2005). Autorka kilku tomów prozy i poezji. Jej ostatnia książka Enerdowce i inne ludzie nominowana była w roku 2011 do Nagrody Literackiej Nike. 